\title{
OFFICIAL DOCUMENTS
}

\section{CONTENTS}

Great Britain. Report of Inter-Imperial Relations Committee of the Imperial Conference, 1926:

I. Introduction $\ldots \ldots \ldots \ldots \ldots \ldots \ldots \ldots \ldots \ldots \ldots \ldots \ldots \ldots \ldots \ldots \ldots \ldots \ldots, 21$

II. Status of Great Britain and the Dominions.................. 21

III. Special Position of India ............................ 22

IV. Relations Between the Various Parts of the British Empire:

(a) The Title of His Majesty the King . . . . . . . . . . . . . . . . . 23

(b) Position of Governors-General ...................... 23

(c) Operation of Dominion Legislation..................... 24

(d) Merchant Shipping Legislation...................... 26

(e) Appeals to the Judicial Committee of the Privy Council ........ 27

V. Relations with Foreign Countries:

(a) Procedure in Relation to Treaties . . . . . . . . . . . . . . . 29

(b) Representation at International Conferences............... 32

(c) General Conduct of Foreign Policy .................... 33

(d) Issue of Exequaturs to Foreign Consuls in the Dominions......... 34

(e) Channel of Communication between Dominion Governments and Foreign Governments........................ 34

VI. System of Communication and Consultation ................ 35

VII. Particular Aspects of Foreign Relations Discussed by Committee:

(a) Compulsory Arbitration in International Disputes........... 36

(b) Adherence of the United States of America to the Protocol establishing the Permanent Court of International Justice.......... 36

(c) The Policy of Locarno ........................... 36

Appendix: Specimen Form of Treaty ........................ 37

Tacna-Arica. Memorandum of the Chilean Minister for Foreign Affairs in reply to the Memorandum of the Secretary of State of Nov. 30, 1926. Dec. 4, 1926. . . 38

- Memorandum handed to the Peruvian Ambassador by the Secretary of State. Dec. 11, 1926................................. 42

. Secretary of

State. Jan. 12, $1927 \ldots \ldots \ldots \ldots \ldots \ldots \ldots \ldots \ldots \ldots \ldots \ldots \ldots \ldots \ldots$ 